\title{
Peran Beberapa Galur Rhizopus microsporus yang Berasal dari "laru tradisional” dalam Menentukan Kualitas Tempe
}

The Role of Some Strains of Rhizopus microsporus Originating from "laru tradisional" in Determining Tempe Quality

Tati Barus*, Fransiska Maya, Anastasia Tatik Hartanti

Program Studi Bioteknologi, Fakultas Teknobiologi, Universitas Katolik Indonesia Atma Jaya, Jakarta

*Korespondensi dengan penulis (tati.barus@atmajaya.ac.id)

Artikel ini dikirim pada tanggal 05 Desember 2018 dan dinyatakan diterima tanggal 20 Februari 2019. Artikel ini juga dipublikasi secara online melalui https://ejournal2.undip.ac.id/index.php/jatp. Hak cipta dilindungi undang-undang. Dilarang diperbanyak untuk tujuan komersial.

Diproduksi oleh Indonesian Food Technologists $($ C)2019

\begin{abstract}
Abstrak
Kualitas tempe ditentukan oleh mikroorganisme yang berperan selama proses fermentasi berlangsung. Mikroorganisme utama dalam fermentasi tempe adalah Rhizopus spp. yang sekarang umumnya berasal dari salah satu jenis laru komersial. Akibatnya, keragaman Rhizopus spp. yang digunakan pada fermentasi tempe mengalami penurunan. Oleh karena itu, penelitian ini bertujuan untuk mendapatkan informasi tentang peran beberapa galur $R$. microsporus yang berasal dari "laru tradisional" dalam menentukan kualitas tempe. Tempe diproduksi menggunakan R. microsporus TB 23 (Tempe TB 23), R. microsporus TB 32 (Tempe TB 32), R. microsporus TB 51 (Tempe TB 51), R. microsporus TB 55 (Tempe TB 55) dan tempe menggunakan laru komersial (Tempe K). Kualitas tempe ditentukan melalui pengukuran tekstur, warna, cita rasa, aktivitas antioksidan, dan komposisi kimia (kadar air, kadar lemak, kadar protein, dan kadar serat kasar). Hasil penelitian menunjukkan bahwa tekstur, warna, dan cita rasa Tempe TB 23, Tempe TB 32, dan Tempe TB 55 sama dengan Tempe K. Demikian juga komposisi kimia Tempe TB 23, Tempe TB 32, dan Tempe TB 55 hampir sama dengan Tempe K. Namun aktivitas antioksidan ketiga jenis tempe tersebut lebih tinggi dibandingkan dengan Tempe K. Tekstur, warna, dan komposisi kimia Tempe TB 23, Tempe TB 32, dan Tempe TB 55 bersama dengan Tempe $\mathrm{K}$ memenuhi syarat mutu tempe yang ditetapkan di Indonesia, yaitu yang tertera pada SNI 3144:2015. Oleh karena itu kesimpulannya adalah $R$. microsporus TB 23, $R$. microsporus TB 32, dan $R$. microsporus TB 55 memiliki potensi untuk dikembangkan sebagai laru komersial untuk fermentasi tempe.
\end{abstract}

Kata kunci: Rhizopus, tempe, kualitas, laru, tradisional, komersial

\begin{abstract}
The quality of tempe was determined by involved microorganisms. The main microorganism in tempe fermentation is Rhizopus spp. which now generally comes from one type of commercial laru. As a result, the diversity of Rhizopus spp. in tempe has decreased. Therefore, this study aims to obtain information about the role of several strains of $R$. microsporus originating from "laru tradisional" in determining the quality of tempe. Tempe was produced using R. microsporus TB 23 (Tempe TB 23), R. microsporus TB 32 (Tempe TB 32), R. microsporus TB 51 (Tempe TB 51), R. microsporus TB 55 (Tempe TB 55), and tempe using commercial laru (Tempe K). The quality of tempeh was determined through measurements of texture, color, taste, antioxidant activity, and chemical composition (moisture content, fat content, protein content, and crude fiber content). The results showed that texture, color and taste of Tempe TB 23, Tempe TB 32, Tempe TB 55 were similar as compared to Tempe K. The antioxidant activity of the three types of tempe was higher than Tempe $K$. The chemical composition of the three types of tempeh was almost similar compared to Tempe K. Texture, color and chemical composition of Tempe TB 23, Tempe TB 32, Tempe TB 55 and Tempe $K$ has fulfilled the quality requirements of tempe in Indonesia, which were listed in SNI 3144: 2015. Therefore, $R$. microsporus TB 23, R. microsporus TB 32 and R. microsporus TB 55 may be developed as commercial inoculums for tempe fermentation.
\end{abstract}

Keywords: Rhizopus, tempe, quality, laru, traditional, commercial

\section{Pendahuluan}

Tempe kedelai (tempe) merupakan pangan fermentasi tradisional Indonesia. Telah dilaporkan tempe mengandung protein tinggi (Radiati dan Sumarto, 2016) dan penting bagi kesehatan karena kaya akan asam lemak tak jenuh (Sudaryatiningsih dan Supyani, 2009). Tempe juga mengandung vitamin $B_{12}$ dan lunasin yang bersifat anti kanker (Hernández-Ledesa et al., 2009). Susilowati et al. (2018) melaporkan bahwa formulasi pasta fortifikan asam folat dapat dihasilkan dengan baik bila dilakukan kombinasi pasta campuran antara tempe dengan sayuran.

Jenis mikroorganisme pada tempe dinilai beragam, seperti adanya bakteri Klebsiella spp. (Barus et al., 2013) dan Bacillus spp. (Barus et al., 2017). Klebsiella spp. dilaporkan sebagai bakteri patogen, tetapi Ayu et al. (2014) melaporkan bahwa Klebsiella spp. tempe berbeda dengan Klebsiella yang patogen.

Mikroorganisme yang beragam dapat menghasilkan kualitas produk fermentasi dengan varian yang berbeda (Polyorach et al., 2018). Hartanti et al. 
(2015) melaporkan tempe Indonesia pada umumnya hanya mengandung Rhizopus microsporus. Omosebi dan Otunola (2013) melaporkan tempe yang difermentasi dengan $R$. oryzae mengandung protein yang lebih tinggi dibandingkan dengan tempe yang difermentasi dengan $R$. oligosporus ataupun $R$. stolonifer. Dengan demikian, jenis Rhizopus yang digunakan pada fermentasi tempe berperan dalam menentukan kualitas tempe.

Laru adalah jenis ragi yang digunakan pada pembuatan fermentasi tempe yang mengandung Rhizopus microsporus yang merupakan kapang atau jamur tempe. Dahulu kala banyak jenis laru tradisional yang dibuat sendiri oleh pengrajin tempe. Salah satu jenis laru tersebut terbuat dari daun waru dari kapang tempe yang ditumbuhkan di daun waru lalu digunakan pada fermentasi tempe. Namun saat ini semua fermentasi tempe menggunakan laru komersial yang diproduksi secara pabrikan dan didominasi oleh satu merek dagang tertentu. Oleh sebab itu, penelitian ini bertujuan untuk mendapatkan informasi tentang potensi beberapa $R$. microsporus dari laru tradisional (daun waru) dalam menentukan kualitas tempe. Hasil penelitian ini bermanfaat dalam penambahan keragaman Rhizopus spp. yang digunakan dalam fermentasi tempe yang saat ini keragamannya menurun. Rhizopus yang digunakan untuk menghasilkan tempe yang memenuhi syarat SNI 3144:2015, yang selanjutnya dapat dikembangkan menjadi laru komersial.

\section{Materi dan Metode}

Materi Penelitian

Sebanyak empat galur $R$. microsporus $(R$. microsporus TB 23, $R$. microsporus TB 32, $R$. microsporus TB 51, dan $R$. microsporus TB 55) digunakan dalam penelitian ini yang merupakan koleksi Fakultas Teknobiologi UNIKA Atma Jaya, kedelai (Bola Merah, USA), laru komersial (Raprima, Indonesia), Potato Dextrose Agar (PDA) (Oxoid, England), etanol 90\% (Emsure, Germany), garam fisiologis 0,85\% (b/v) (Merck, Germany), 2,2-diphenyl-1-picrylhydrazyl (DPPH) (Aldrich, Germany), dan asam asetat 25\% (Dixi, Indonesia).

Peralatan yang digunakan dalam penelitian ini terdiri atas freeze dryer (Christ, Germany), hemasitometer (Improved Neubauer, Marienfield), inkubator (Memmert, Germany), incubator shaker (GFL, Germany), mikroskop cahaya (Olympus CX 21, China), spektrofotometer (Optima Sp 3000-plus, Jepang), timbangan analitik (Shimadzu ATX 224, Japan), dan vortex (Thermolyne Tipe 37680 Mixer, USA).

\section{Penyiapan suspensi spora galur $R$. microsporus}

Tahap ini menggunakan metode Sudaryatiningsih dan Supyani (2009) yang dimodifikasi. Sebanyak empat galur Rhizopus yang digunakan pada penelitian ini ditumbuhkan pada media agar cawan Potato Dextrose Agar (PDA) yang diinkubasi pada suhu $30^{\circ} \mathrm{C}$ selama 8 hari. Suspensi spora masing-masing Rhizopus dipanen dengan memasukkan $5 \mathrm{ml}$ garam fisiologi 0,85\% (b/v) pada agar cawan PDA dan diaduk dengan ose loop. Tujuannya untuk mendapatkan suspensi spora keempat galur Rhizopus untuk digunakan dalam pembuatan tempe. Jumlah spora yang digunakan pada setiap pembuatan tempe adalah $10^{7}$ spora/ml yang dihitung menggunakan hemasitometer.

\section{Prosedur Pembuatan Tempe}

Perlakuan dalam pembuatan tempe yang diterapkan pada penelitian tersaji pada Tabel 1. Secara garis besar tahapan yang dilakukan pada pembuatan tempe adalah berdasarkan pada penelitian Radiati dan Sumarto (2016), namun terdapat beberapa modifikasi, salah satunya adalah penggunaan air steril untuk menghindari keterlibatan mikroorganisme selain kapang Rhizopus.

Proses pembuatan tempe diawali dengan pembersihan dan dilanjutkan perebusan kedelai selama 40 menit. Kemudian kedelai ditiriskan, kulit ari dikupas dan dibuang. Kedelai sebanyak $500 \mathrm{~g}$ direbus kembali selama 15 menit, ditiriskan dan dibilas sebanyak tiga kali dengan air steril yang mendidih. Selanjutnya, kedelai direndam selama 5 jam pada air yang telah diturunkan pHnya dengan asam asetat menjadi $\mathrm{pH} 4,5$. Setelah perendaman, kedelai ditiriskan dan dikeringkan dengan kain steril. Lalu disiapkan 10 kantong plastik untuk diisi dengan $50 \mathrm{~g}$ kedelai kemudian dicampur dengan $0,33 \mathrm{ml}$ suspensi spora $\left(10^{7} \mathrm{spora} / \mathrm{ml}\right)$ masingmasing galur $R$. microsporus. Setelah diaduk rata, plastik diberi lubang kemudian diinkubasi selama 48 jam di dalam inkubator pada suhu $30^{\circ} \mathrm{C}$. Untuk tempe $\mathrm{K}$ (Tabel 1) ditambahkan 0,3 g laru komersial pada $50 \mathrm{~g}$ kedelai yang telah siap untuk difermentasi, diaduk hingga rata, lalu diinkubasi selama 48 jam di dalam inkubator pada suhu $30^{\circ} \mathrm{C}$. Pembuatan tempe diulang tiga kali.

\section{Analisis Organoleptik}

Analisis organoleptik tempe dilakukan dengan uji hedonik oleh 44 orang panelis tidak terlatih dengan mengikuti metode Lawless and Heymann (2013). Kriteria penilaian meliputi warna, aroma, tekstur, dan rasa tempe. Sampel tempe yang disajikan kepada setiap penelis, berukuran $1 \times 2 \mathrm{~cm}$ dan telah dikukus selama 10 menit. Panelis memberikan penilaian terhadap tempe dengan memilih angka 1, 2, 3, 4 masing-masing menunjukkan sangat tidak suka, tidak suka, suka, dan sangat suka. Analisis organoleptik diulang sebanyak tiga kali.

\section{Pengukuran Aktivitas Antioksidan}

Pengukuran aktivitas antioksidan dilakukan dengan menggunakan DPPH yang diawali dengan persiapan $100 \mathrm{~g}$ sampel masing-masing tempe dan 100 g kedelai yang dikeringbekukan dengan freeze dryer selama 15 jam. Ekstraksi dan pengukuran aktivitas antioksidan dari masing-masing tepung tempe dan tepung kedelai dilakukan sesuai dengan metode Pabesak et al. (2013). Pengukuran aktivitas antioksidan diulang sebanyak tiga kali. 
Tabel 1. Kode dan sumber Rhizopus yang digunakan pada pembuatan tempe

\begin{tabular}{lll}
\hline Tempe & \multicolumn{3}{c}{ Sumber Rhizopus dalam pembuatan tempe } \\
\hline K & $0,3 \mathrm{~g}$ Laru komersil & \\
TB 23 & $0,33 \mathrm{ml}$ suspensi spora $\left(10^{7} \mathrm{spora} / \mathrm{ml}\right)$ & R. microsporus TB 23 dari "laru tradisional" \\
TB 32 & $0,33 \mathrm{ml}$ suspensi spora $\left(10^{7} \mathrm{spora} / \mathrm{ml}\right)$ & R. microsporus TB 32 dari "laru tradisional" \\
TB 51 & $0,33 \mathrm{ml}$ suspensi spora $\left(10^{7} \mathrm{spora} / \mathrm{ml}\right)$ & R. microsporus TB 51 dari "laru tradisional" \\
TB 55 & $0,33 \mathrm{ml}$ suspensi spora $\left(10^{7} \mathrm{spora} / \mathrm{ml}\right)$ & R. microsporus TB 55 dari "laru tradisional" \\
\hline
\end{tabular}

Tabel 2. Data uji organoleptik tempe K, tempe TB 23, tempe TB 32, tempe TB 51 dan tempe TB 55

\begin{tabular}{lccccc}
\hline \multirow{2}{*}{ Parameter } & \multicolumn{5}{c}{ Tempe } \\
\cline { 2 - 6 } & $\mathrm{K}$ & TB 23 & TB 32 & TB 51 & TB 55 \\
\hline Warna & $3,25 \pm 1,03^{\mathrm{a}, \mathrm{b}}$ & $3,68 \pm 0,95^{\mathrm{a}}$ & $3,50 \pm 0,91^{\mathrm{a}}$ & $2,93 \pm 1,15^{\mathrm{b}}$ & $3,45 \pm 0,95^{\mathrm{a}, \mathrm{b}}$ \\
Aroma & $3,58 \pm 1,11^{\mathrm{a}}$ & $3,41 \pm 0,84^{\mathrm{a}}$ & $3,39 \pm 0,92^{\mathrm{a}}$ & $3,53 \pm 1,04^{\mathrm{a}}$ & $3,26 \pm 0,86^{\mathrm{a}}$ \\
Tekstur & $3,18 \pm 0,84^{\mathrm{a}}$ & $3,34 \pm 0,90^{\mathrm{a}}$ & $3,23 \pm 1,03^{\mathrm{a}}$ & $3,19 \pm 1,09^{\mathrm{a}}$ & $3,271,13^{\mathrm{a}}$ \\
Rasa & $2,50 \pm 1,09^{\mathrm{a}}$ & $2,96 \pm 1,04^{\mathrm{a}, \mathrm{b}}$ & $3,00 \pm 0,95^{\mathrm{a}, \mathrm{b}}$ & $3,05 \pm 1,10^{\mathrm{a}, \mathrm{b}}$ & $3,22 \pm 1,14^{\mathrm{b}}$ \\
After taste & $2,35 \pm 1,00^{\mathrm{a}}$ & $2,96 \pm 1,03^{\mathrm{b}}$ & $3,14 \pm 0,97^{\mathrm{b}}$ & $3,14 \pm 1,14^{\mathrm{b}}$ & $3,27 \pm 1,15^{\mathrm{b}}$ \\
\hline
\end{tabular}

Keterangan: nilai yang diikuti dengan huruf yang sama pada baris yang sama menunjukkan nilai yang tidak berbeda nyata pada $a=5 \%$. Tempe K (menggunakan laru komersial). Tempe TB 23 ( $R$. microsporus TB 23 dari "laru tradisional"), Tempe TB 32 (R. microsporus TB 32 dari "laru tradisional"), Tempe TB 51 (R. microsporus TB 51 dari "laru tradisional"), Tempe TB 55 ( R. microsporus TB 55 dari "laru tradisional").

Analisis Proksimat Tempe

Analisis proksimat tempe dilakukan sesuai standar internasional AOAC edisi ke-19 tahun 2012 (AOAC, 2012). Pengukuran kadar air dan lemak dilakukan dengan metode Gravimetri. Kadar protein dengan metode analisis auto destruksi. Kadar serat kasar dengan metode ekstraksi asam basa. Analisis proksimat dilakukan di Balai Penelitian Ternak, Bogor. Pengukuran komposisi kimia dilakukan satu kali (tanpa pengulangan) namun dinilai dapat dipertanggungjawabkan karena persiapan sampel tempe sudah dilakukan dengan sangat baik dan analisis dilakukan di Balai Penelitian Ternak yang telah tersertifikasi KAN.

\section{Analisis Data}

Data organoleptik dan aktivitas antioksidan dianalisis dengan One-Way ANOVA dengan level signifikan yang ditetapkan sebesar 0,5 yang dibantu dengan software statistik SPSS.

\section{Hasil dan Pembahasan}

Tempe K, tempe TB 23, tempe TB 32, tempe TB 51, dan TB 55 telah berhasil diproduksi seperti yang tertera pada Gambar 1 sebagai perwakilan dari semua perlakuan. Salah satu tahapan penting dalam fermentasi tempe adalah proses pengasaman kedelai, yaitu pada tahapan perendaman kedelai sebelum dicampur dengan Rhizopus. Pengasaman kedelai penting agar Rhizopus dapat tumbuh (Radiati dan Sumarto, 2016). Selain itu, umumnya bakteri asam laktat berperan penting dalam pengasaman tersebut (Barus et al., 2008). Namun proses pengasaman kedelai pada penelitian ini digunakan asam asetat sehingga $\mathrm{pH}$ mencapai 4,5 dan tempe berhasil diproduksi. Hal ini dilakukan untuk menghindari keterlibatan mikroorganisme lain dalam menentukan kualitas tempe.

\section{Uji Organoleptik}

Pada penelitian ini ditemukan tiga warna tempe yang berbeda yaitu putih merata (tempe K), putih dengan spot-spot kekuningan (tempe TB 23 , tempe TB 32 , dan tempe TB 55), serta putih keabu-abuan (tempe TB 51) sebagaimana tampil pada Gambar 1. Berdasarkan analisis ragam diketahui bahwa kesukaan panelis terhadap warna tempe $\mathrm{K}$, tempe TB 23 , tempe TB 32, dan tempe TB 55, berbeda tidak nyata (Tabel 2). Namun, warna keempat jenis tempe tersebut berbeda nyata dengan warna tempe TB 51. Warna tempe TB 51 paling tidak disukai oleh panelis.

Warna putih pada tempe merupakan warna dari miselium kapang (Radiati dan Sumarto, 2016) yang mengikat kedelai. Kriteria warna tempe yang baik berdasarkan SNI (2015) adalah warna putih yang merata pada seluruh permukaannya. Berdasarkan SNI (2015) tersebut maka hanya tempe $\mathrm{K}$ yang memiliki warna yang sesuai dengan kriteria tersebut sedangkan tempe TB 23, tempe TB 32, dan tempe TB 55 tidak sesuai dengan SNI karena terdapat spot-spot kekuningan. Terbentuknya spot-spot kekuningan pada TB 23, tempe TB 32, dan tempe TB 55 tersebut merupakan hal yang menarik untuk dikaji lebih lanjut. Hal ini karena ketiga Rhizopus tersebut menunjukkan potensi untuk membentuk senyawa tertentu sehingga terbentuk spot-spot kekuningan. Telah dilaporkan ada galur $R$. microsporus tertentu mampu menghasilkan pigmen $\beta$-karoten (Sudaryatiningsih dan Supyani, 2009). Pigmen $\beta$-karoten telah dilaporkan berperan dalam menangkal radikal bebas (Fiedor dan Burda, 2014) Potensi ini turut ditunjukkan oleh aktivitas antioksidan terhadap radikal DPPH dari ketiga tempe yang membentuk spot kuning.

Tempe TB 51 berwarna putih keabu-abuan (Gambar 1). Warna tersebut merupakan penampakan dari pigmen spora kapang yang lebih awal terbentuk (Omosebi dan Otunola, 2013). Hasil penelitian ini menunjukkan $R$. microsporus TB 51 lebih cepat membentuk spora dibandingkan $R$. microsporus lainnya. Sifat ini kurang baik bila digunakan pada tempe, karena spora kapang yang cepat terbentuk pada tempe menjadi kurang menarik bagi panelis karena menimbulkan warna yang lebih gelap (Omosebi dan Otunola, 2013). 
Analisis ragam menunjukkan bahwa persepsi panelis terhadap rasa tempe $\mathrm{K}$, tempe TB 23, tempe TB 32, dan tempe TB 51 tidak berbeda nyata. Namun rasa empat jenis tempe tersebut berbeda nyata dengan rasa tempe TB 55, dan tempe TB 55 ini merupakan tempe yang paling disukai oleh panelis atau yang paling enak (Tabel 2). Rasa tempe dapat timbul akibat terbentuknya peptida atau asam amino karena $R$. microsporus menghasilkan enzim selama proses fermentasi berlangsung (Witono et al., 2015). Ukuran peptida dan jenis asam amino menjadi penentu rasa pahit, gurih ataupun asam pada tempe (Barus et al., 2008).

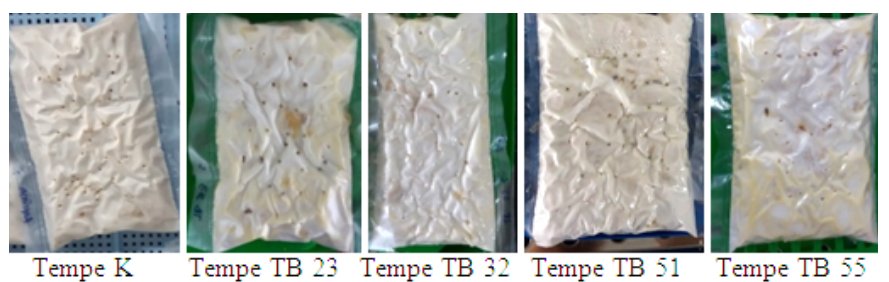

Gambar 1. Hasil dari tempe yang berhasil diproduksi. Tempe $\mathrm{K}$ (menggunakan laru komersial), Tempe TB 23 ( $R$. microsporus TB 23 dari "laru tradisional"), Tempe TB 32 ( $R$. microsporus TB 32 dari "laru tradisional"), Tempe TB 51 ( $R$. microsporus TB 51 dari "laru tradisional"), Tempe TB 55 ( $R$. microsporus TB 55 dari "laru tradisional").

Analisis ragam menunjukkan bahwa aroma dari kelima tempe tidak menunjukkan perbedaan yang nyata (Tabel 2). Ketiga tempe memiliki aroma khas tempe dan tidak ditemukan bau amoniak, namun aroma tempe tersebut dapat berbeda-beda tergantung pada hasil dari interaksi antara substrat dan kapang serta mikroorganisme lain yang digunakan untuk fermentasi tempe (Puteri et al., 2014).

Kriteria tempe yang baik menurut SNI (2015) adalah bila miselium memenuhi ruang antar butiran kedelai sehingga teksturnya kompak dan tidak hancur bila dipotong. Berdasarkan analisis ragam menunjukkan bahwa tekstur dari kelima tempe yang kompak tidak menunjukkan adanya perbedaan yang nyata (Tabel 2) dan semua jenis tempe dalam penelitian ini telah memenuhi kriteria tempe yang baik.

Tekstur kompak dari tempe yang diproduksi dinilai pada saat dipotong, ditekan, atau dikunyah. Menurut Radiati dan Sumarto (2016), tekstur tempe dipengaruhi oleh miselium kapang dan kondisi inkubasi. Kualitas miselium kapang ditentukan oleh jenis kapang (spesies atau varian Rhizopus spp.) yang digunakan. Kondisi inkubasi terdiri atas aerasi yaitu ketersediaan oksigen untuk pertumbuhan kapang, serta suhu inkubasi yang sesuai dengan suhu optimum pertumbuhan kapang (Radiati dan Sumarto, 2016).

\section{Aktivitas Antioksidan}

Analisis ragam menunjukkan bahwa aktivitas antioksidan tempe nyata lebih tinggi dibandingkan dengan aktivitas antioksidan kedelai (Gambar 2). Selain itu, aktivitas antioksidan tempe TB 23, tempe TB 32, dan tempe TB 55 nyata lebih tinggi dibandingkan tempe $\mathrm{K}$ dan tempe TB 51. Proses fermentasi kedelai menjadi tempe menyebabkan meningkatnya aktivitas antioksidan (Ferreira et al., 2011), sesuai dengan hasil penelitian yang menunjukkan aktivitas antioksidan tempe yang lebih tinggi dibandingkan dengan kedelai (Gambar 2). Hal ini kemungkinan karena adanya hubungan antara kandungan isoflavon dengan aktivitas antioksidan kedelai. Penurunan kadar isoflavon glukosida pada kedelai dan peningkatan kadar isoflavon aglikon dapat terjadi akibat adanya aktivitas $\beta$ glukosidase pada kedelai selama proses fermentasi (Ferreira et al., 2011). Tinggi-rendahnya aktivitas antioksidan dapat dipengaruhi oleh kemampuan Rhizopus spp. dalam menghasilkan $\beta$-glukosidase yang berbeda-beda (Krisch et al., 2010).

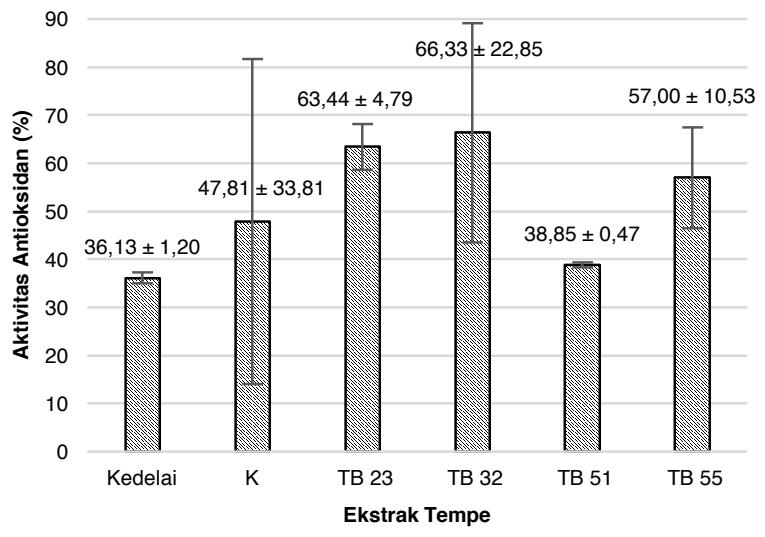

Gambar 2. Aktivitas antioksidan tempe K, tempe TB 23, tempe TB 32, tempe TB 51 dan tempe TB 55. Tempe K (menggunakan laru komersial). Tempe TB 23 ( $R$. microsporus TB 23 dari "laru tradisional"), Tempe TB 32 ( $R$. microsporus TB 32 dari "laru tradisional"), Tempe TB 51 (R. microsporus TB 51 dari "laru tradisional"), Tempe TB 55 ( $R$. microsporus TB 55 dari "laru tradisional").

Selain dari senyawa isoflavon, aktivitas antioksidan dapat dipengaruhi oleh kehadiran peptida bioaktif (Endrawati dan Kusumaningtyas, 2017) ataupun adanya pigmen $\beta$-karoten (Fiedor dan Burda, 2014) yang diketahui memiliki peranan mengikat oksigen singlet ataupun reactive oxygen species (ROS) lainnya. Pada penelitian ini, tempe TB 23, tempe TB 32, dan tempe TB 55 aktivitas antioksidannya lebih tinggi dibandingkan tempe tempe $\mathrm{K}$ dan tempe TB 51 yang dapat ditunjukkan adanya penampakan spot-spot warna kuning yang diperkirakan menunjukkan $\beta$ karoten.

\section{Analisis proksimat tempe}

Komposisi kimia protein tempe berkisar antara 43,98-44,68\% (Tabel 3). Tampak bahwa tempe TB 23, tempe TB 32, tempe TB 51, dan tempe TB 55 yang berasal dari laru tradisional menghasilkan protein yang tinggi. Kadar protein semua tempe yang diteliti memenuhi syarat mutu tempe yang tertera pada SNI 3144:2015, yaitu minimal 15\%. Bavia et al. (2012) melaporkan kadar protein tempe sekitar 41,62-51,99\% yang memiliki kemiripan dengan tempe pada penelitian ini.

Protein pada tempe lebih berkualitas dibandingkan dengan kedelai karena adanya pemecahan protein 
kompleks menjadi peptida dan asam amino bebas yang memiliki berat molekul rendah sehingga lebih mudah larut (Endrawati dan Kusumaningtyas, 2017). Hal ini menjadikan tempe sebagai salah satu sumber protein nabati bagi masyarakat Indonesia yang tidak dapat mengonsumsi protein hewani.

Tabel 3. Data analisis proksimat (dalam \%) tempe $\mathrm{K}$, tempe TB 23, tempe TB 32, tempe TB 51 dan tempe TB 55 menggunakan metode analisis AOAC

\begin{tabular}{lcccc}
\hline $\begin{array}{l}\text { Jenis } \\
\text { tempe }\end{array}$ & $\begin{array}{c}\text { Kadar } \\
\text { Protein }\end{array}$ & $\begin{array}{c}\text { Kadar } \\
\text { Lemak }\end{array}$ & $\begin{array}{c}\text { Kadar } \\
\text { air }\end{array}$ & $\begin{array}{c}\text { Kadar } \\
\text { Serat kasar }\end{array}$ \\
\hline K & 44,68 & 17,98 & 12,88 & 4,31 \\
TB 23 & 44,55 & 19.33 & 8,30 & 4,08 \\
TB 32 & 44,15 & 16,90 & 10,13 & 4,85 \\
TB 51 & 44,13 & 17,23 & 12,12 & 4,94 \\
TB 55 & 43,98 & 17,71 & 9,96 & 5,21
\end{tabular}

Keterangan: Tempe K (menggunakan laru komersial). Tempe TB 23 ( $R$. microsporus TB 23 dari "laru tradisional"), Tempe TB 32 ( $R$. microsporus TB 32 dari "laru tradisional"), Tempe TB 51 ( $R$. microsporus TB 51 dari "laru tradisional"), Tempe TB 55 ( $R$. microsporus TB 55 dari "laru tradisional").

Kadar lemak paling rendah diperoleh pada tempe TB 32 yaitu 16,90\% dan paling tinggi pada tempe TB 23 yaitu $19,33 \%$. Nilai kadar lemak tersebut mendekati dengan yang dilaporkan oleh Bavia et al. (2012), yaitu sekitar 20,95-24,06\%. Meski demikian, kadar lemak dari kelima tempe yang diproduksi telah memenuhi syarat SNI (2015) yaitu tidak kurang dari 7\%. Kadar lemak yang bervariasi dapat dipengaruhi oleh substrat (Radiati dan Sumarto, 2016) ataupun keragaman aktivitas lipase dari Rhizopus. Peranan lipase pada fermentasi tempe adalah untuk memecah triasilgliserol menjadi asam lemak bebas dan digunakan untuk pertumbuhan kapang (Radiati dan Sumarto, 2016).

Kadar air Tempe TB 23, Tempe TB 32, Tempe TB 51, Tempe TB 55, dan Tempe $\mathrm{K}$ berkisar 8,30$2,88 \%$. Dengan demikian kadar air dari semua tempe pada penelitian ini memenuhi mutu tempe SNI 3144:2015, yaitu maksimal $65 \%$. Kadar serat kasar dari Tempe TB 23, Tempe TB 32, Tempe TB 51, Tempe TB 55, dan Tempe $\mathrm{K}$ berkisar 4,08-5,21 \% namun tidak sesuai dengan SNI 3144:2015, yaitu maksimal 2,5\%. Kandungan serat kasar yang berbeda dengan SNI dapat dipengaruhi oleh jenis kedelai dan lama fermentasi (Widoyo et al., 2015). Durasi fermentasi berhubungan dengan pertumbuhan kapang karena terjadi perbanyakan hifa yang tersusun atas selulosa yang merupakan komponen penyusun serat kasar. Serat kasar tidak memiliki nilai gizi namun berperan dalam menjaga kesehatan saluran cerna seperti menghindari konstipasi, mengencerkan zat beracun dan zat karsinogenik (Widoyo et al., 2015).

\section{Kesimpulan}

Tekstur, warna, dan komposisi kimia Tempe TB 23, Tempe TB 32, Tempe TB 55 bersama dengan Tempe $\mathrm{K}$ dinilai memenuhi sebagian besar syarat mutu tempe yang ditetapkan SNI 3144:2015. Oleh karena itu, $R$. microsporus TB 23, $R$. microsporus TB 32, dan $R$. microsporus TB 55 memiliki potensi untuk dikembangkan sebagai laru komersial untuk fermentasi tempe.

\section{Daftar pustaka}

AOAC (Association of Official Analytical Chemists). 2012. Official Methods of Analysis, 19th Edition. Arlington.

Ayu, E., Suwanto, A., Barus, T. 2014. Klebsiella pneumoniae from Indonesian tempeh were genetically different from that of pathogenic isolates. Microbiology Indonesia 8(1):9 -15. DOI:10.5454/ mi.8.1.2.

Barus, T., Hanjaya, I., Sadeli, J., Lay, B.W., Suwanto, A., Yulandi, A. 2013. Genetic diversity of Klebsiella spp. isolated from tempe based on enterobacterial repetitive intergenic consensus-polymerase chain reaction (ERIC-PCR). HAYATI Journal of Biosciences. 20(4):171-176. DOI:10.4308/hjb. 20.4.171.

Barus, T., Suwanto, A., Wahyudi, A.T., Wijaya, H. 2008. Role of bacteria in tempe bitter taste formation: microbiological and molecular biological analysis based on 16S rRNA gene. Microbiology Indonesia 2(1):17-21. DOI: $10.5454 / \mathrm{mi} .2 .1 .4$.

Barus T., Wati, L., Melani, Suwanto, A., Yogiara. 2017. Diversity of protease-producing Bacillus spp. From Fresh Indonesian tempeh based on 16S rRNA gene sequence. HAYATI Journal of Biosciences 24(1):3540. DOI: DOI:10.1016/j.hjb.2017.05.001.

Bavia, A.C.F., Silvia, C.E., Ferreira, M.P., Leite, R.S., Mandarino, J.M.G., Carrao-Panizzi, M.C. 2012. Chemical composition of tempeh from soybean cultivars specially developed for human consumption. Ciencia e Tecnologia de Alimentos 32(3):613-620. DOI:10.1590/S0101-20612012 005000085.

Endrawati, D., Kusumaningtyas, E. 2017. Beberapa fungsi Rhizopus sp dalam meningkatkan nilai nutrisi bahan pakan. WARTAZOA 27(2):081-088. DOI:10.14334/wartazoa.v27i2.1181.

Ferreira, M.P., Oliveria, M.C.N., Mandarino, J.M.G., Silva, J.B., Ida, E.I., Panizzi, M.C.C. 2011. Changes in the isoflavone profile and in the chemical composition of tempeh during processing and refrigeration. Pesquisa Agropecuaria Brasileira 46(11):1555-1561. DOI:10.1590/S0100-204X2011 001100018.

Fiedor, J., Burda, K. 2014. Potential role of carotenoids as antioxidants in human health and disease. Nutrients 6(2):466:468. DOI:10.3390/nu6020466.

Hartanti, A.T., Rahayu, G., Hidayat, I. 2015. Rhizopus species from fresh tempeh collected from several regions in Indonesia. HAYATI 22(3):136-142. DOI: 10.1016/j.hjb.2015.10.004.

Hernández-Ledesa, B., Hsieh, C-C., O. de Lumen, Ben. 2009. Lunasin and Bowman-Birk protease inhibitor (BBI) in US commercial soy foods. Food Chemistry 115(2):574-580. DOI: 10.1016/j.foodchem.2008. 12.054

Krisch, J., Papp, T., Tako, M., Vágvölgyi, C. 2010. Characteristics and potential use of $\beta$-glucosidases 
from Zygomycetes. Current Research, Technology and Education Topics in Applied Microbiology and Microbial Biotechnology 891-896.

Omosebi, M.O., Otunola, E.T. 2013. Preliminary studies on tempeh flour produced from three different Rhizopus species. International Journal of Biotechnology and Food Science 1(5):90-96.

Pabesak, R.V., Dewi, L., Lestario, L.N. 2013. Aktivitas antioksidan dan fenolik total pada tempe dengan penambahan biji labu kuning (Cucurbita moschata ex Poir). Di dalam: Seminar Nasional X Pendidikan Biologi FKIP UNS. Surakarta, 6 Juli 2013. HIm 1-7.

Polyorach, S., Wanapat, M., Poungchompu, O., Cherdthong, A., Gunun, P., Gunun, N., Kang, S. 2018. Effect of fermentation using different microorganisms on nutritive values of fresh and dry cassava root. Asian Journal of Animal and Veterinary Advances 13(2):128-135. DOI:10.3923/ajava.2018. 128.135.

Puteri, M.D.P.T.G., Hassanein, T.R., Prabawati, E.K., Wijaya, C.H., Mutukumira, A.N. 2015. Sensory characteristics of seasoning powders from overripe tempeh, a solid state fermented soybean. Procedia Chemistry 14(2015):263-269. DOI:10.1016/j.proche. 2015.03.037.

Radiati, A., Sumarto. 2016. Analisis sifat fisik, sifat organoleptik, dan kandungan gizi pada produk tempe dari kacang non-kedelai. Jurnal Aplikasi Teknologi Pangan 5(1):16-22. DOI:10.17728/jatp. v5i1.32.
SNI (Standar Nasional Indonesia) 3144-2015. 2015. Tempe Kedelai. Badan Standarisasi Nasional. Jakarta.

Sudaryatiningsih, C., Supyani. 2009. Linoleic and linolenic acids analysis of soybean tofu with Rhizopus oryzae and Rhizopus oligosporus as coagulant. Nusantara Bioscience 1(3):110-116. DOI: 10.13057/nusbiosci/n010302

Susilowati, A., Maryati, Y., Lotulung, P.D.N., Aspiyanto. 2018. Formulasi nikstamal jagung, tempe, dan sayuran terfermentasi dalam perolehan pasta fortifikan sebagai sumber asam folat alami. Jurnal Aplikasi Teknologi Pangan 5(7): 68-74. DOI: 10.17728/jatp.2517.

Widoyo, S., Handajani, S., Nandariyah. 2015. Pengaruh lama fermentasi terhadap kadar serat kasar dan aktivitas antioksidan tempe beberapa varietas kedelai. Biofarmasi 13(2): 59-65. DOI:10.13057/ biofar/f130203

Witono, Y., Widjanarko, S.B., Mujianto, Rachmawati. 2015. Amino acids identification of over fermented tempeh, the hydrolysate and the seasoning product hydrolysed by calotropin from crown flower (Calotropis gigantea). International Journal on Advance Science Engineering Information Technology 5(2):103-106. DOI:10.18517/ ijaseit.5.2. 494. 